Article

\title{
A Study of the Protective Properties of Iraqi Olive Leaves against Oxidation and Pathogenic Bacteria in Food Applications
}

\author{
Ammar B. Altemimi \\ Department of Food Science, College of Agriculture, University of Basrah, Basrah 61004, Iraq; \\ ammar.ramddan@uobasrah.edu.iq or ammaragr@siu.edu \\ Academic Editors: Antonio Segura-Carretero and Elena Alañon \\ Received: 8 April 2017; Accepted: 15 May 2017; Published: 17 May 2017
}

\begin{abstract}
There is an ancient and prodigious history of olive trees because of their nutritional, medicinal, and traditional uses. Intensive studies have been conducted on olive leaves because they have many positive and beneficial effects for human health. In this study, different solvents were used to examine the olive leaves for their antioxidant and antimicrobial activities and their possible food applications. The obtained results showed that the amounts of phenolic compounds of the olive leaf were $190.44 \pm 0.50,173 \pm 1.72,147.78 \pm 0.69$, and $147.50 \pm 0.05 \mathrm{mg}$ gallic acid $/ \mathrm{g}$ extracts using methanol, ethanol, diethyl ether, and hexanol, respectively. The statistical analysis revealed that there was a significant difference in the phenolic contents in terms of the used solvents. The stability of the olive leaves extraction was also studied and the results indicated that increasing the storage temperature could negatively affect and encourage the degradation of the phenolic compounds. Furthermore, the olive leaf extraction was applied to raw sheep meat slides at $0.5 \%$, $1.5 \%$, and $2.5 \%(\mathrm{w} / \mathrm{v})$ in order to test its antioxidant and antimicrobial effects. The results obviously showed that the sample treated with $2.5 \%$ olive leaf extract had the significantly $(p<0.05)$ lowest Thiobarbituric Acid (TBA) values of $1.92 \pm 0.12$ (mg Malonaldehyde MDA $/ \mathrm{kg}$ ) throughout 12 days of cold storage. Moreover, the results showed that the sample, which was treated with $2.5 \%$ olive leaf extract, had low total bacterial count and total coliform bacteria $(6.23 \pm 0.05,5.2 \pm 0.35$ log colony forming unit (CFU)/g, respectively) among the control, $0.5 \%$, and $1.5 \%$ olive leaf treated samples throughout 12 days of storage. The phenolic extracts from the olive leaf extract had significant antioxidant and antimicrobial activities, which could be used as a source of potential antioxidant and antimicrobial agents.
\end{abstract}

Keywords: Olive leaf; TBA; antioxidant; antimicrobial; coliform

\section{Introduction}

Olive trees are known as trees of the subtropical region, which can survive and live for a few decades. The original homeland of olive trees is the Mediterranean region, including Iraq [1]. The estimated area of planted olive trees is approximately eight million hectares. In addition, many studies pointed out that the cultivation of olive trees began around 3500 years ago [2]. The olive leaf is one of the tree byproducts, which are obtained through either the pruning and harvesting process or fall due to different climatic factors. There is an ancient and prodigious history of olive trees because of their nutritional, medicinal, and traditional uses [3]. An essential part of the Mediterranean diet is olive products because of their ability to modulate and control the oxidative balance in vivo; indeed, they can monitor and inhibit pathogenic bacteria $[4,5]$.

Lipid oxidation has been one of the major concerns of the scientific community for centuries. Scientists are persistently looking for antioxidants that will adequately work against oxidation in both 
fats and oils [6]. Synthetic antioxidants are used in most countries, and their usage level is regulated and the safety of the compounds has been tested based on long-term toxicity studies. Moreover, most of the synthetic antioxidants are stable either under processing conditions or under the storage status of oils and fats [7]. However, these synthetic antioxidants can cause carcinogenic and toxicological effects [8]. There are no decisive results on the safety of these materials, thus utilizing antioxidants from natural sources has arisen throughout the world [9].

There is an intensive investigation of olive leaves because of their many positive and beneficial effects for human health. For instance, olive leaves can work as anti-inflammatory, anti-microbial, anti-diabetic, anti-atherosclerotic, and anti-carcinogenic agents $[10,11]$. Nowadays, people are consuming and taking olive leaf extracts that can be in either liquid or capsule form. Oleuropein is considered one of the most abundant phenolic compounds in olive leaf extracts [12]. In fact, Oleuropein possess a spectacular effect against many foodborne pathogens such as Staphylococcus aureus, Helicobacter pylori, and Campylobacter jejuni [11]. Haddadin [13] found that olive tree leaves possessed large amounts of phenolic compounds such as vannilin, vannilic acid, verbascoside, luteolin-7-glucoside, and catechin; and their qualities were similar to those that are found in olives and other products derived from them, thus possessing the ability to prevent oxidation in food.

The main objectives of this study are; (1) to investigate the antioxidant and antimicrobial properties of olive leaf extract (OLE), (2) to determine the olive leaf extract chemical composition, and (3) to monitor the effects of using olive leaf extract on the quality of raw sheep meat slides.

\section{Materials and Methods}

\subsection{Preparation of the Olive Leaf Extracts}

Olive leaves were collected from an olive orchard located in Najaf province, Iraq. They were placed in polyethylene bags and kept in the refrigerator until use, and then the olive leaves were characterized by specialists at the Department of Horticulture, College of Agriculture, University of Basra. The olive leaves were cleaned and properly washed from extraneous matter. Then, they were dried in a hot air-oven for $48 \mathrm{~h}$ at $37^{\circ} \mathrm{C}$. A powder form of the dried olive leaves was obtained after crushing them in a blender. Thereafter, the olive leaf extracts were prepared according to Pereira et al. [10] by using the mixed solvents as follow:

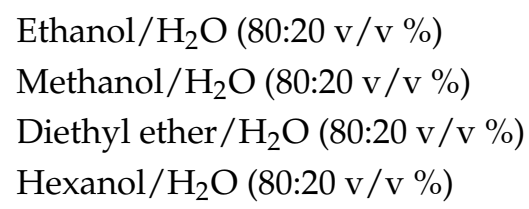

Five grams of powdered olive leaves was weighed and placed in a $500 \mathrm{~mL}$ beaker with the addition of $200 \mathrm{~mL}$ of each solvent separately. The solvent extraction process was performed at a temperature of $38{ }^{\circ} \mathrm{C}$ using a stirrer speed of $180 \mathrm{rpm}$ for $20 \mathrm{~min}$ followed by filtration using Whatman no.1. Centrifugation was performed at $5000 \mathrm{r} / \mathrm{min}$ for $15 \mathrm{~min}$, and then the filtrates were evaporated at $38^{\circ} \mathrm{C}$ using a rotary evaporator for $4 \mathrm{~h}$. The crude extracts were kept in dark containers in the refrigerator before use.

\subsection{Determination of Total Phenolic Compounds}

The total phenolic compounds were measured according to Lako et al. [14] with slight modifications. One $\mathrm{mL}$ of crude olive extract was mixed with $20 \mathrm{~mL}$ of (DMSO) dimeyhyl sulfuoxide. Afterwards, $2.5 \mathrm{~mL}$ of Folin-Ciocalteu was added with the addition of $10 \mathrm{~mL}$ of distilled water. The mixture was left for $2.5 \mathrm{~min}$ at room temperature. Then $2 \mathrm{~mL}$ of sodium carbonate $(7.5 \%)$ was added, and the mixture was kept for one hour at room temperature in a dark place. The absorbance was read at a wavelength of $725 \mathrm{~nm}$, and it was compared to a calibration curve prepared with 
known amounts of Gallic acid (Roth, Karlsruhe, Germany). The results were expressed as mg Gallic acid/g extracts.

\subsection{Ferric Thiocyanate}

The antioxidant activity of the olive leaves was measured according to Elmastas et al. [15], which included measuring the effectiveness of the anti-oxidation of linoleic acid by mixing $1 \mathrm{~mL}$ of the crude extract with $4 \mathrm{~mL}$ of ethanol (95\%), $4.1 \mathrm{~mL}$ of linoleic acid (2.5\%) in ethanol, and $8 \mathrm{~mL}$ of phosphate buffer $(0.05 \mathrm{M}, \mathrm{pH} 7)$. The mixture was incubated at a temperature of $45{ }^{\circ} \mathrm{C}$ for $24 \mathrm{~h}$, and then $0.1 \mathrm{~mL}$ of this mixture was added to $9.7 \mathrm{~mL}$ of ethanol $(75 \%), 0.1 \mathrm{~mL}$ of ammonium thiocyanate $(30 \%)$, and $0.1 \mathrm{~mL}$ of ferrous chloride $(0.02 \mathrm{M})$. All conditions were the same for preparing the control sample except for mixing $1 \mathrm{~mL}$ of distilled water instead of the sample extracts. The synthetic antioxidant butylated hydroxytoluene (BHT) was used as a model for comparison. The absorbance was measured at a wavelength of $500 \mathrm{~nm}$ using a UV-Spectrophotometer. The percentage of antioxidant activity was calculated as follows:

$\%$ Antioxidant activity $=100-(\mathrm{A} / \mathrm{B}) \times 100$

A: Absorbance of thesample

B: Absorbance of thecontrol

\subsection{Ferric Reducing Antioxidant Power}

The antioxidant ability of the olive leaves was determined according to [16]. One $\mathrm{mL}$ of olive leaf extract was dissolved in $1 \mathrm{~mL}$ of distilled water, and $2.5 \mathrm{~mL}$ of $\mathrm{K}_{3} \mathrm{Fe}(\mathrm{CN})_{6}(1 \% \mathrm{w} / \mathrm{v})$ with $2.5 \mathrm{~mL}$ of $0.2 \mathrm{M}$ phosphate buffer ( $\mathrm{pH}$ 6.6). The mixture was kept at $50{ }^{\circ} \mathrm{C}$ for $20 \mathrm{~min}$, and then about $22.5 \mathrm{~mL}$ of trichloro acetic acid $(10 \% \mathrm{w} / \mathrm{v})$ was added. Afterwards, centrifugation at $3000 \mathrm{rpm}$ for $10 \mathrm{~min}$ was performed in order to obtain an upper layer $(2.5 \mathrm{~mL})$. Then $2.5 \mathrm{~mL}$ of distilled water and $0.5 \mathrm{~mL}$ of $\mathrm{FeCl}_{3}(0.1 \%, \mathrm{w} / \mathrm{v})$ were mixed with the obtained upper layer. All conditions were the same for preparing the control sample except for mixing $1 \mathrm{~mL}$ of distilled water instead of the sample extracts. The synthetic antioxidant (BHT) was used as a model for comparison. The absorbance was measured at $700 \mathrm{~nm}$ using a spectrophotometer. The ferric reducing antioxidant power was calculated as follows:

$\%$ Ferric reducing antioxidant power $=100-\left(\mathrm{A}_{\mathrm{s}} / \mathrm{A}_{\mathrm{c}}\right) \times 100$

$\mathrm{A}_{\mathrm{s}}=$ absorbance of the sample

$\mathrm{A}_{\mathrm{c}}=$ absorbance of the control

\subsection{Free Radical Scavenging Activity}

Firstly, the 1,1-diphenyl-2-picrylhydrazyl (DPPH) solution was prepared by dissolving $2 \mathrm{mg}$ of this indicator in $100 \mathrm{ml}$ of methanol. Secondly, the DPPH solution $(3 \mathrm{~mL})$ was added to $1 \mathrm{~mL}$ of olive leaf extract and was then mixed gently according to [17]. The mixture was incubated in a dark place for $30 \mathrm{~min}$. The control sample was prepared by mixing $1 \mathrm{~mL}$ of methanol with $3 \mathrm{~mL}$ of the prepared DPPH solution. The synthetic antioxidant (BHT) was used as a model for comparison. The absorbance was measured at $517 \mathrm{~nm}$ for each sample using a spectrophotometer. The inhibition of DPPH activity was calculated using the following formula:

$\%$ Inhibition of DPPH activity $=\left[\mathrm{A}_{\mathrm{c}}-\mathrm{A}_{\mathrm{s}} / \mathrm{A}_{\mathrm{c}}\right] \times 100$

$\mathrm{A}_{\mathrm{c}}$ : absorbance of the control

$\mathrm{A}_{\mathrm{s}}$ : absorbance of the sample

\subsection{Studying the Stability of the Olive Leaf Extract}

The preliminary results indicated that methanol extraction showed the highest values for the tested performance among the used solvents. For this reason, methanol extraction was used in the 
remainder of the experiments. The storage times and temperatures for the olive leaf were tested to ensure that there was minimal change for the total phenolic compounds, in order to avoid degradation of the phenolic compounds. Concentrated olive leaf extracts were stored at $-18{ }^{\circ} \mathrm{C}, 5{ }^{\circ} \mathrm{C}, 25^{\circ} \mathrm{C}$, and $35{ }^{\circ} \mathrm{C}$ for 75 days. The total phenolic compounds were monitored every 15 days.

\subsection{Determination of the Olive Leaf Extract Profile}

The reversed phase HPLC with silica-based C18 was used as the stationary phase for determination of oleuropein, tyrosol, and verbascoside from the olive leaf extract. The mobile phase was a mixture of water and acetonitrile ( $80 / 20$ volume ratio) containing $1 \%$ acetic acid at a flow rate of $1.0 \mathrm{~mL} / \mathrm{min}$. Oleuropein, tyrosol, and verbascoside in the crude olive leaf were identified by comparing their retention times with the corresponding standards [18].

\subsection{Application of the Olive Leaf Extract on the Sheep Meat Slides}

\subsubsection{Preparation of Sheep Meat Samples}

The sheep meat was obtained from local markets in Basra province. The sheep meat was cut into different sizes of slides (approximately $15 \times 15 \mathrm{~cm}^{3}$ ). The weight of the sheep meat slides was about $10 \mathrm{~g}$ for each slide. The sheep meat slides were divided into five batches; three batches of sheep meat slides were immersed in solutions containing $0.5 \%, 1.5 \%$, and $2.5 \%$ OLE $(\mathrm{w} / \mathrm{v})$ in a 1:1 ratio (sheep meat:distilled water $\mathrm{w} / \mathrm{v}$ ) for $15 \mathrm{~h}$ at $5{ }^{\circ} \mathrm{C}$. After treatment, the samples were drained. The fourth batch was used as a control sample by immersion in distilled water. Ziploc bags were used to keep the sheep meat slides in five portions and were stored at $5{ }^{\circ} \mathrm{C}$ for 12 days.

\subsection{2. $\mathrm{pH}$ Determination of the Sheep Meat Slides}

The $\mathrm{pH}$ of the sheep meat slides was estimated according to Aytul et al. [19]. Approximately 2-2.5 $\mathrm{g}$ of sheep meat slides were weighed and mixed with distilled water $(1: 10 \mathrm{w} / \mathrm{v})$. Centrifugation was performed at 12,000 rpm for $4 \mathrm{~min}$ in order to homogenize the mixture of sheep meat slides and distilled water. The $\mathrm{pH}$ of treated and non-treated samples was measured in triplicate by a $\mathrm{pH}$ meter.

\subsection{Determination of Oxidative Stability of the Sheep Meat Slides}

\subsubsection{Thiobarbituric Acid (TBA) Assay}

The TBA assay was carried out according to Bekhit et al. [20] with slight modifications. Firstly, the solution of TBA $(0.45 \%)$ and trichloroacetic acid (TCA) (prepared in $0.25 \mathrm{~N} \mathrm{HCl}$ ) was prepared. Then 2.5 grams of treated sheep meat slides $(0.5 \%, 1.5 \%$, and $2.5 \% \mathrm{w} / \mathrm{v})$ were mixed and homogenized at 10,000 rpm for $5 \mathrm{~min}$ in a beaker containing $25 \mathrm{~mL}$ of the prepared solution of TBA and TCA. Then, in order to develop a pink color, approximately $5 \mathrm{~mL}$ of the homogenized sample was placed in a water bath at $100{ }^{\circ} \mathrm{C}$ for $12 \mathrm{~min}$. The boiled samples were cooled under tap water. Thereafter, centrifugation at $5000 \mathrm{rpm}$ for $15 \mathrm{~min}$ was performed. The whole procedure was repeated by using distilled water instead of the olive leaf extract (control sample), while BHT was used for comparison. Finally, the absorbance of the treated samples was measured at $532 \mathrm{~nm}$ using a spectrophotometer. The TBA value was calculated as follows: TBA [mg Malonaldehyde (MDA) equivalent $/ \mathrm{kg}$ sheep meat] $=\mathrm{A} \times 7.8$, where A: the absorbance.

\subsubsection{Antimicrobial Activity of the Olive Leaf Extract on Sheep Meat Slides}

The antimicrobial activity of the olive leaf extract was determined according to Andrews [21] with slight modifications. Approximately $10 \mathrm{~g}$ of treated sheep meat slides $(0.5 \%, 1.5 \%$, and $2.5 \% \mathrm{w} / \mathrm{v})$ was mixed and homogenized with $90 \mathrm{~mL}$ of $0.1 \%$ sterile peptone water under sterilized conditions for $2 \mathrm{~min}$ at $25{ }^{\circ} \mathrm{C}$. The serial dilution of the mixture was made using $0.1 \%$ peptone water. The diluted samples were transferred to a petri dish containing nutrient agar and MacConkey agar in order to 
determine both the total count bacteria and total coliform bacteria, respectively. Microbial counts were expressed as $\log _{10} \mathrm{CFU} / \mathrm{g}$ of the sample.

\subsection{Statistical Data Analysis}

The SPSS statistical software program (SPSS for Windows version 17, Spss Inc., Chicago, IL, USA) was used to analyze the data. Data were expressed as mean \pm standard deviation (SD). The obtained results were considered significant at $p<0.05$.

\section{Results and Discussion}

\subsection{Total Phenolic Contents}

The total phenolic content of the olive leaves was expressed and presented in terms of mg gallic acid/g extracts (Figure 1a). The obtained results showed that the amount of phenolic compounds of the olive leaf were $190.44 \pm 0.50,173 \pm 1.72,147.78 \pm 0.69$, and $147.50 \pm 0.05 \mathrm{mg}$ gallic acid/g extracts using methanol, ethanol, diethyl ether, and hexanol, respectively. The statistical analysis revealed that there was a significant difference in the phenolic contents in terms of the solvents used. Among all the solvents, methanol extraction gave the highest amount of phenolic compounds followed by ethanol extraction, while the lowest amount of phenolic compounds was obtained using either diethyl ether or hexanol extraction. These results were in agreement with Zhou and Yu [22], who mentioned that using polar solvents could surely enhance and provide the highest amount of phenolic compounds in the examined plants.

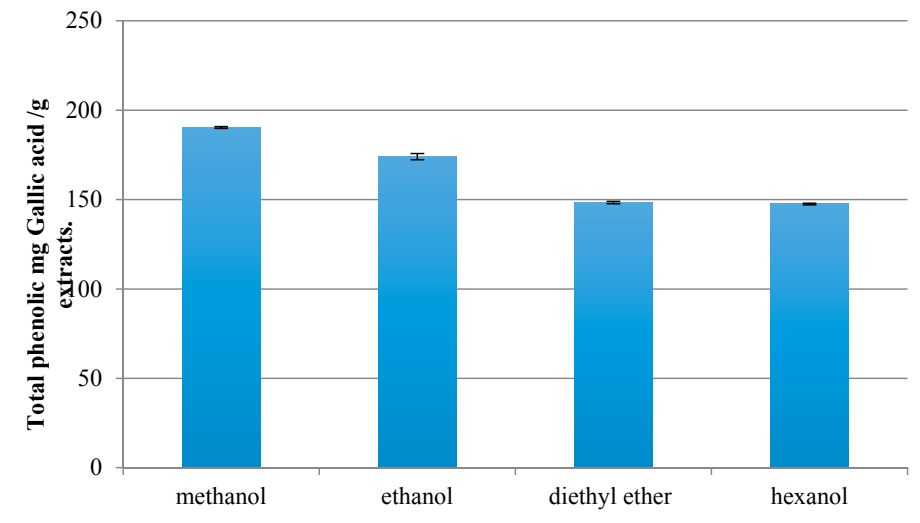

(a)

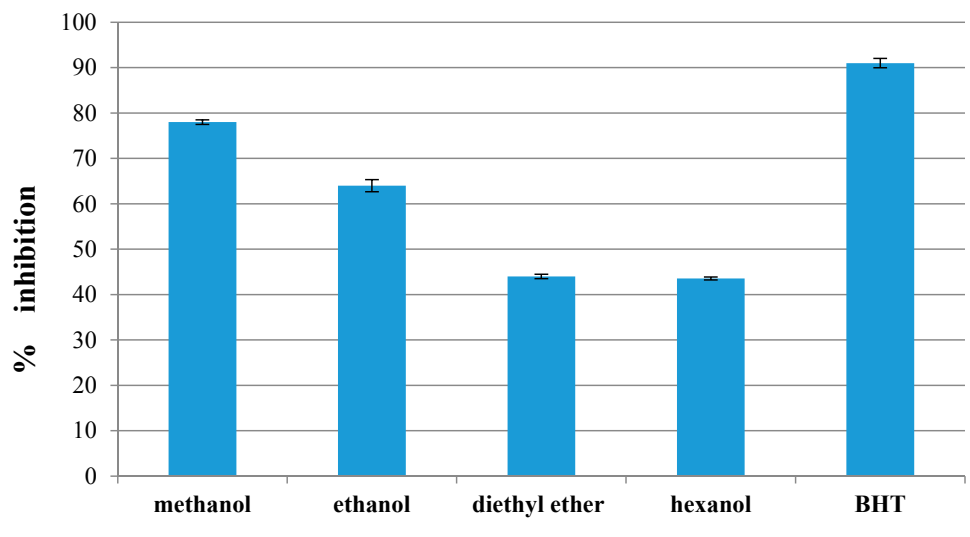

(b)

Figure 1. Cont. 


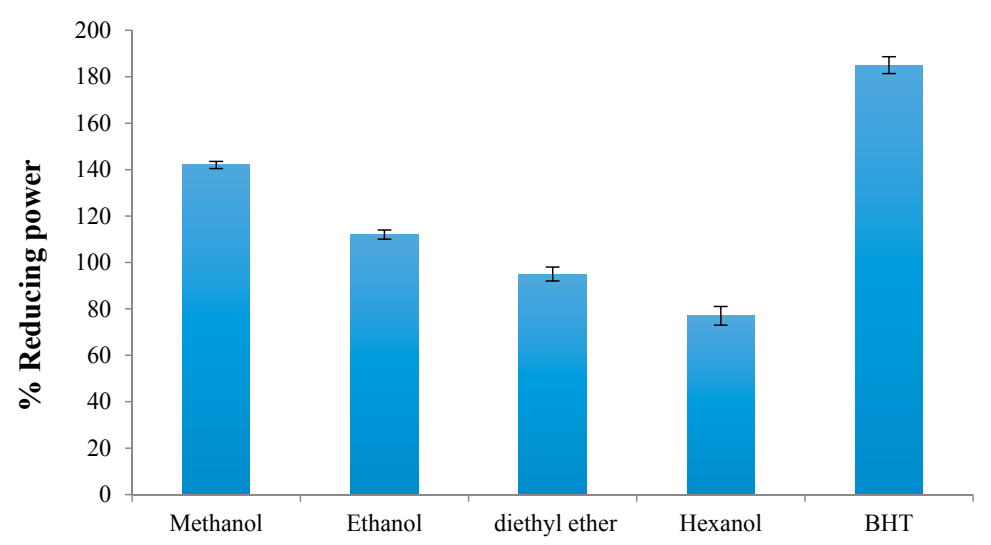

(c)

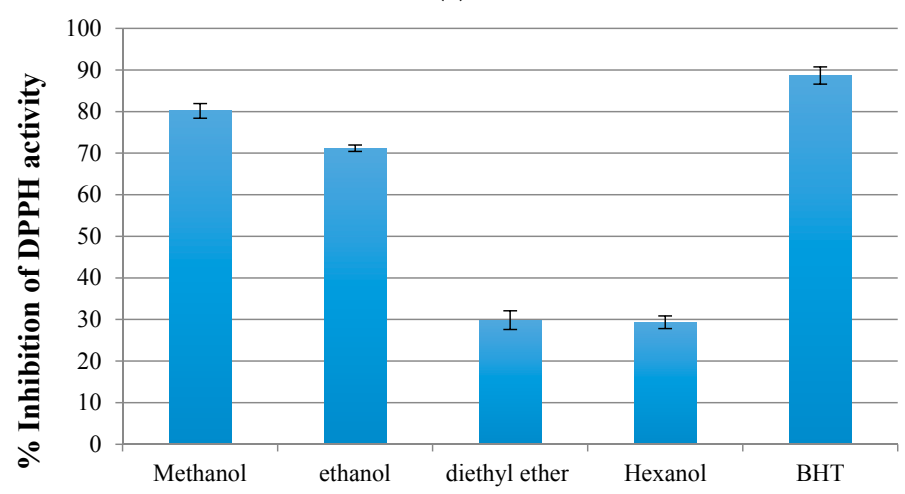

(d)

Figure 1. (a) Total phenolic content of the olive leaf. (b) Percentage of inhibition of linoleic acid peroxidation. (c) Percentage of reducing power of the olive leaf extracts. (d) DPPH radical scavenging activity of different plant extracts.

\subsection{Antioxidant Properties}

The antioxidant property of the olive leaf was estimated using diverse methods in order to obtain accurate results.

\subsubsection{Ferric Thiocyanate Method}

The results indicated that methanol extraction of the olive leaves showed the strongest extraction $(78 \% \pm 0.5)$, while the percentage of inhibition of the ethanol extraction was $(63 \% \pm 1.32)$ (Figure 1b). Both diethyl ether and hexanol gave the lowest percentage of inhibition ( $44 \% \pm 0.5$ and $43.92 \% \pm 0.34$, respectively). These results confirm the superior ability of methanol for the extraction of phenolic compounds, which own the effectiveness of the anti-oxidant and thus give it a significantly higher effectiveness than other solvents. Furthermore, the statistical analyses found that the percentage of inhibition of the methanol extract and ethanolic extract were significantly $(p<0.05)$ lower than the percentage of inhibition of BHT $(92.17 \% \pm 1.04)$. These results were consistent with that indicated by Ilango et al. [23] in their study of the antioxidant activity of the leaf plant Adhatoda zeylanica using the methanol extract. 


\subsubsection{Total Reducing Power}

The reducing power capability of the olive leaf extract compared with BHT is examined in Figure 1c. The reducing power of the methanol extraction of the olive leaf was found to be remarkable and significant $(p<0.05)$ compared to the other solvents' extraction. The percentage of reducing power was $143.3 \% \pm 1.52,114.13 \% \pm 1.80$, and $183.8 \% \pm 1.08$ for the methanol extraction, ethanolic extraction, and BHT, respectively. Furthermore, the statistical analyses found that there was no significant difference between diethyl ether extraction and hexanol extraction. This result was in agreement with Aliyu et al. [24] who measured the reductive power of the methanol extract of the Bauhinia rufescens leaf, and found that there was a potential effect for this extract to be used as a reducing factor by emitting a hydrogen atom and thus quenching free radicals. Moreover, the reductive capability depended on the ability of the plant extract and BHT to convert $\mathrm{Fe}^{+3}$ to $\mathrm{Fe}^{+2}$, thus giving the highest values of the reducing power.

\subsubsection{DPPH Radical Scavenging Assay}

First, the antioxidant activity of the olive leaf extracts was investigated using the DPPH scavenging method by measuring the total antioxidant capacity. In this study, the effectiveness of the olive leaf extracts using different solvents was compared with the synthetic antioxidant BHT. The methanol extract of the olive leaves had a significant effect $(80.166 \% \pm 1.75)$ on the inhibition of DPPH activity among all the solvents used (Figure 1d). In contrast, BHT exhibited the highest antioxidant activity $(88.67 \% \pm 2.08)$ by decolorizing the DPPH reagent and then changing the absorbance reading positively. Both diethyl ether and hexanol extracts were found to be less active against DPPH $(29.83 \% \pm 2.25$, $29.33 \% \pm 1.53)$, respectively. This finding was similar to that of Gkanatsiou et al. [8], who found that more polar solvents had the ability to penetrate and dissolve more polar phenolic compounds from the olive leaf. The obtained results were not in an agreement with Hamad [25], who reported that the percentage of inhibition of the Saudi olive leaf was $(51.72 \% \pm 0.66)$ using ethanol extraction. The reason may be ascribed to the differences between the cultivars used.

\subsection{Comparison between Total Phenolics Compounds' and Antioxidant Activities' Methods Performance}

The preliminary results indicated that methanol extraction showed the highest values for the tested performance among the solvents used. For this reason, the correlation between total phenolic compounds' and antioxidant activities' methods performance depended on the methanol extraction. The researchers measured the value of $\mathrm{R}^{2}$ in order to determine if the data exhibited a linear relationship. A low correlation $\left(R^{2}=0.157\right)$ between the phenolic compounds and the percent inhibition of DPPH activity was indicated; this low correlation was also mentioned by Rezaeizadeh et al. [26], who explained and suggested that the decreasing radical scavenging values may be ascribed to the weakness of the DPPH oxidizing agent when the highest amount of phenolic compounds are present.

A weak correlation $\left(R^{2}=0.355\right)$ was shown between the values of phenolic compounds of the olive leaf extract and the ferric thiocyanate assay. Thus, the value of $\mathrm{R}^{2}$ of the ferric thiocyanate assay and the total phenolic content was found to have an unacceptable fit line. This obtained result may be related to the purification process and concentration of phenolic compounds during the preparation of the olive leaf extract.

The correlation between the total phenolic content and the reducing power activity was assigned. The regression analysis $(y=1.6429 x-143.14)$ showed a strong correlation $\left(R^{2}=0.994\right)$ between the total phenolic content and the reducing power activity. This result confirms that the plant extracts with the highest amount of phenolic content will be more effective at scavenging free radicals. These findings were in an agreement with Altemimi et al. [27] and Fernandez-Gutierrez [28], who discovered that the phenolic profile was considered very important to show the relation between the abovestated categories. 


\subsection{Stability of the Olive Leaf Extract}

Figure 2 shows the estimated variation of the total phenolic content of the methanol extraction of the olive leaves. The differences between the stored samples were investigated using the $T$-test at $95 \%$ confidence level. The statistical analysis found that there was no significant difference $(p>0.05)$ between the stored samples at the freezing temperature at $-18{ }^{\circ} \mathrm{C}$ nor the cooling temperature at $4{ }^{\circ} \mathrm{C}$ for up to 75 days. However, the obtained results revealed that there was a significant difference $(p<0.05)$ between both $25^{\circ} \mathrm{C}$ and $35^{\circ} \mathrm{C}$. The total recovery of phenolic compounds for both $25^{\circ} \mathrm{C}$ and $35{ }^{\circ} \mathrm{C}$ was $49.75 \%$ and $27 \%$, respectively, when the olive leaf extract was stored for 75 days. This result indicated that increasing the storage temperature could negatively affect and encourage the degradation of the phenolic compounds. These findings were in an agreement with Obied et al. [29] who studied the effect of the storage condition on the phenolic compound and antioxidant activity of olive mill waste.

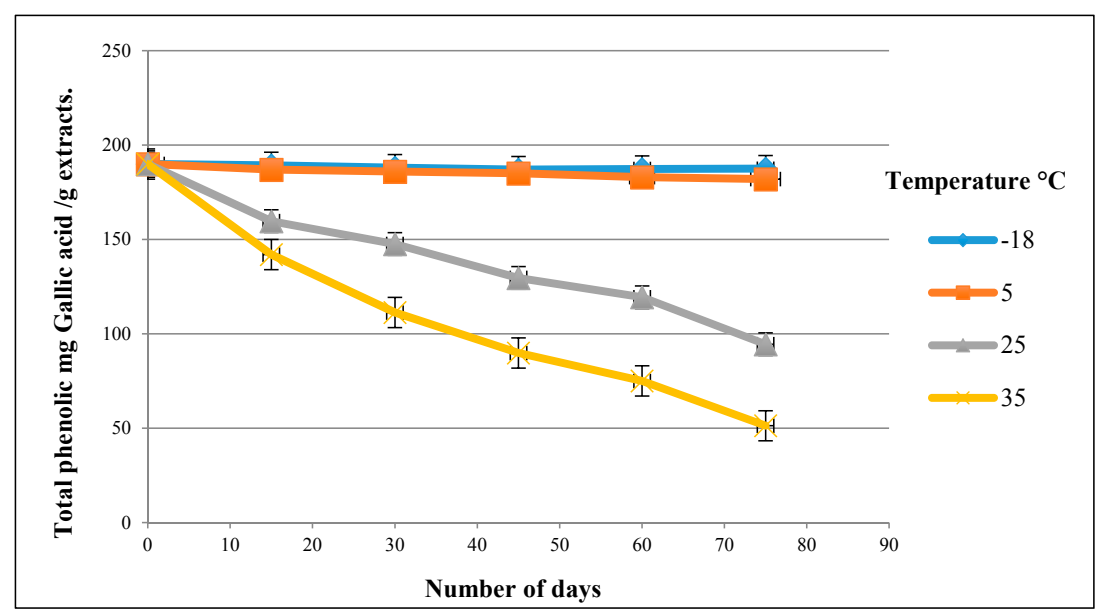

Figure 2. Stability of the olive leaf extract at different temperatures over a period of 75 days.

\subsection{Olive Leaf Extract Profile}

The methanol extracts of the olive leaves were examined by HPLC with ion trap mass spectrometry (IT-MS) and three major compounds (verbascoside, oleuropein, and tyrosol) were identified (Figure 3). The corresponding references of verbascoside, oleuropein, and tyrosol were used to compare the retention times with unknown phenolic constituents of the crude olive leaf extract, and then quantified all of them by using the calibration curves (Figure 4).

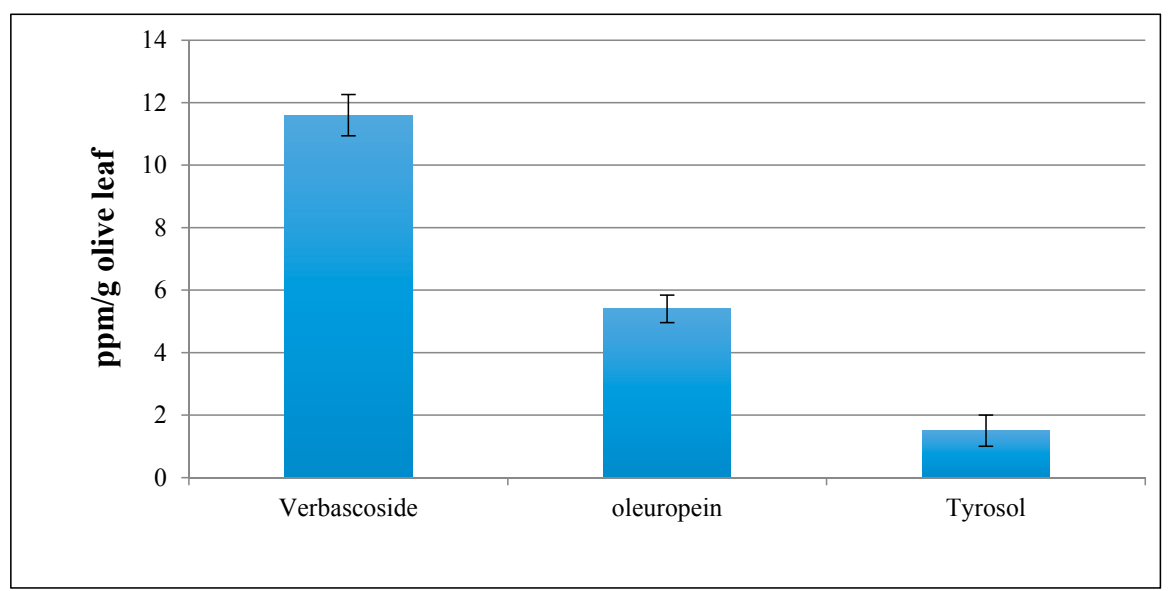

Figure 3. Olive leaf extract profile. 


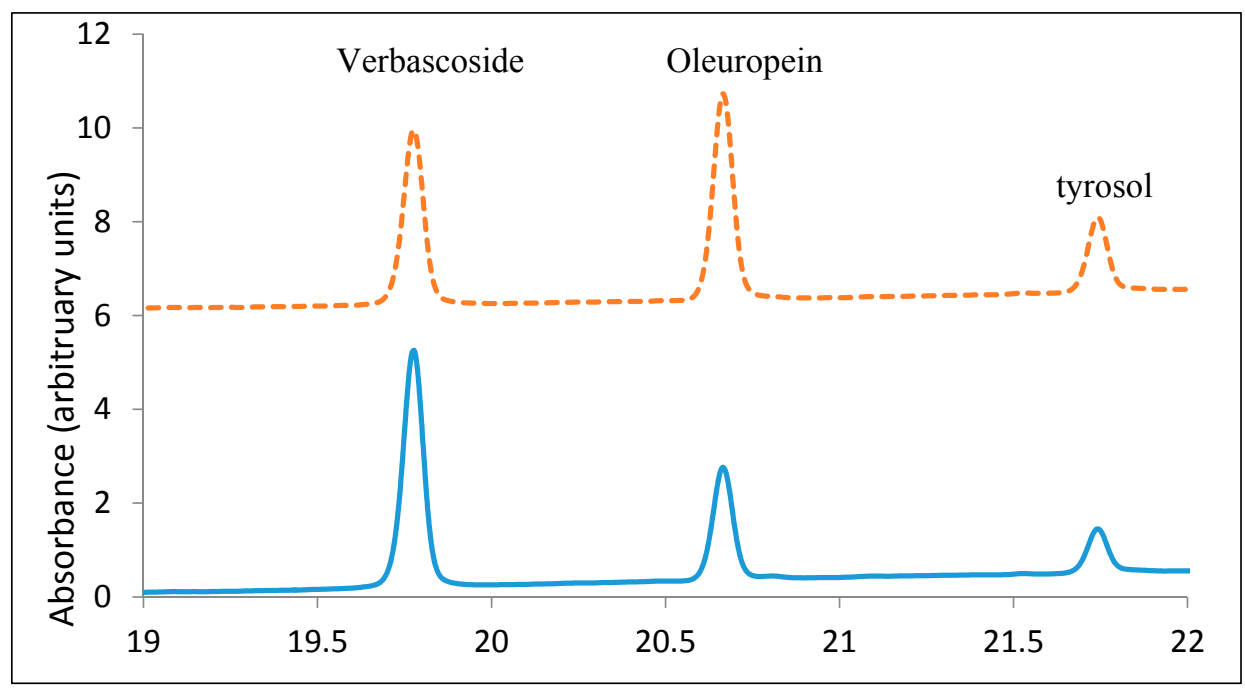

Figure 4. HPLC chromatogram of the olive leaf methanol extracts and the standards.

\subsection{Application of the Olive Leaf Extract on Sheep Meat Slides}

\section{pH Determination of the Sheep Meat Slides}

First, the $\mathrm{pH}$ of the raw meat was estimated to be 6.44 (Table 1). The statistical analysis revealed that there was no significant difference $(p>0.05)$ between the control samples and all the treated sheep meat slides with either $0.5 \%$ or $1.5 \%$ olive leaf extracts through six days of cold storage. However, the sample treated with $1.5 \%$ olive leaf extract had a low $\mathrm{pH}$ value at eight days of cold storage compared to the control and $0.5 \%$ olive leaf extract treatment. In contrast, the sample treated with $2.5 \%$ olive leaf extract had significantly $(p<0.05)$ lower $\mathrm{pH}$ values $(6.29 \pm 0.05)$ during the whole 12 days of cold storage.

Table 1. Effect of the olive leaf extract on $\mathrm{pH}$ values of the sheep meat slide.

\begin{tabular}{ccccc}
\hline \multirow{2}{*}{ Treatment } & \multicolumn{4}{c}{ Number of Days $^{*}$} \\
\cline { 2 - 5 } & $\mathbf{2}$ & $\mathbf{4}$ & $\mathbf{8}$ & $\mathbf{1 2}$ \\
\hline Control & $6.53 \pm 0.02^{\mathrm{a}}$ & $6.55 \pm 0.02^{\mathrm{a}}$ & $6.66 \pm 0.03^{\mathrm{a}}$ & $6.75 \pm 0.03^{\mathrm{a}}$ \\
$0.5 \%$ olive leaf & $6.52 \pm 0.03^{\mathrm{a}}$ & $6.54 \pm 0.02^{\mathrm{a}}$ & $6.62 \pm 0.03^{\mathrm{a}}$ & $6.74 \pm 0.02^{\mathrm{a}}$ \\
$1.5 \%$ olive leaf & $6.52 \pm 0.02^{\mathrm{a}}$ & $6.52 \pm 0.02^{\mathrm{c}}$ & $6.49 \pm 0.03^{\mathrm{b}}$ & $6.73 \pm 0.04^{\mathrm{a}}$ \\
$2.5 \%$ olive leaf & $6.39 \pm 0.03^{\mathrm{b}}$ & $6.36 \pm 0.02^{\mathrm{b}}$ & $6.32 \pm 0.02^{\mathrm{c}}$ & $6.29 \pm 0.03^{\mathrm{b}}$ \\
\hline
\end{tabular}

* Means within each column with the same superscript letter $\left({ }^{\mathrm{a}, \mathrm{b}, \mathrm{c}}\right)$ are not significantly different.

\subsection{Determination of Oxidative Stability of Sheep Meat Slides}

Thiobarbituric Acid (TBA) Assay

The lipid oxidation was determined using TBA analysis as an index (Table 2). The statistical analysis showed that there was no significant difference $(p>0.05)$ between the control samples and all the treated sheep meat slides with either $0.5 \%$ or $1.5 \%$ olive leaf extract through four days of cold storage. However, the sample treated with $1.5 \%$ olive leaf extract had a low TBA value at eight days of cold storage compared to the control and $0.5 \%$ olive leaf extract treatment. Increasing TBA values using either $0.5 \%$ or $1.5 \%$ olive leaf extract could be related to an extremely lower concentration of antioxidant material within each sample. In contrast, the sample treated with $2.5 \%$ olive leaf extract had significantly $(p<0.05)$ lower TBA values $(1.92 \pm 0.12 \mathrm{mg}$ MDA $/ \mathrm{kg})$ throughout the 12 days of cold storage. Moreover, the results revealed that the BHT treatment exhibited the lowest TBA values 
$(1.44 \pm 0.17) \mathrm{mg}$ MDA $/ \mathrm{kg}$ among the olive leaf concentrations except for $2.5 \%$. This result was similar to that discovered by Verma and Sahoo [30]. Scientists said that if the TBA value was less than $2 \mathrm{mg}$ $\mathrm{MDA} / \mathrm{kg}$ meat, the plant extracts would be accepted as good quality.

Table 2. Effect of the olive leaf extract on TBA values (mg MDA / $\mathrm{kg}$ ) of the sheep meat slides stored at $5{ }^{\circ} \mathrm{C}$ for 12 days.

\begin{tabular}{ccccc}
\hline \multirow{2}{*}{ Treatment } & \multicolumn{4}{c}{ Number of Days * } \\
\cline { 2 - 5 } & $\mathbf{2}$ & $\mathbf{4}$ & $\mathbf{8}$ & $\mathbf{1 2}$ \\
\hline Control & $2.24 \pm 0.15^{\mathrm{a}}$ & $3.76 \pm 0.23^{\mathrm{a}}$ & $4.68 \pm 0.18^{\mathrm{a}}$ & $5.75 \pm 0.10^{\mathrm{a}}$ \\
$0.5 \%$ olive leaf & $2.27 \pm 0.06^{\mathrm{a}}$ & $3.73 \pm 0.20^{\mathrm{a}}$ & $4.69 \pm 0.06^{\mathrm{a}}$ & $5.76 \pm 0.02^{\mathrm{a}}$ \\
$1.5 \%$ olive leaf & $2.23 \pm 0.06^{\mathrm{a}}$ & $3.72 \pm 0.03^{\mathrm{a}}$ & $4.09 \pm 0.11^{\mathrm{b}}$ & $4.92 \pm 0.04^{\mathrm{b}}$ \\
$2.5 \%$ olive leaf & $1.27 \pm 0.15^{\mathrm{b}}$ & $1.33 \pm 0.06^{\mathrm{b}}$ & $1.69 \pm 0.12^{\mathrm{c}}$ & $1.92 \pm 0.12^{\mathrm{c}}$ \\
BHT 0.02\% & $0.99 \pm 0.12^{\mathrm{c}}$ & $1.12 \pm 0.16^{\mathrm{c}}$ & $1.22 \pm 0.21^{\mathrm{d}}$ & $1.44 \pm 0.17^{\mathrm{d}}$ \\
\hline
\end{tabular}

* Means within each column with the same superscript letter $(\mathrm{a}, \mathrm{b}, \mathrm{c}, \mathrm{d})$ are not significantly different.

\subsection{Antimicrobial Activity of the Olive Leaf Extract on Total Count Bacteria of the Sheep Meat Slides}

Table 3 shows the effect of different concentrations of the olive leaf extract on the total count bacteria of the refrigerated stored sheep meat slides. The preliminary investigation measured the total count bacteria of the fresh sheep meat slides, which was $3.5 \log$ CFU/g. After that, the total count bacteria dramatically increased during 12 days of storage at $5{ }^{\circ} \mathrm{C}$ in both the control sample and the sheep meat slides treated with olive leaf extracts. The statistical data analysis showed that there was no significant difference $(p>0.05)$ between either the control sample and the $0.5 \%, 1.5 \%$, and $2.5 \%$ olive leaf extracts during three days of cold storage, while the $1.5 \%$ and $2.5 \%$ olive leaf extract were statistically significant compared to control sample and the $0.5 \%$ olive leaf extract during the same period of time. There was significant differences between the $1.5 \%$ and $2.5 \%$ olive leaf extracts at 6 , 9 , and 12 days of the cold storage condition. Moreover, the results showed that the sample treated with the $2.5 \%$ olive leaf extract had low microbial counts $(6.23 \pm 0.05 \log \mathrm{CFU} / \mathrm{g})$ compared to the control, $0.5 \%$, and $1.5 \%$ olive leaf extract treated samples after 12 days of the cold storage condition. This finding was in an agreement with that of Ahmed et al. [31], who found that using increasing concentrations of olive leaf extracts as antibacterial compounds had a powerful effect in controlling the microbial load of raw peeled shrimp.

Table 3. Effect of the olive leaf extract on total count bacteria $(\log \mathrm{CFU} / \mathrm{g})$ of the sheep meat slides stored at $5{ }^{\circ} \mathrm{C}$ for 12 days.

\begin{tabular}{ccccc}
\hline \multirow{2}{*}{ Treatment } & \multicolumn{4}{c}{ Number of Days * $^{\text {* }}$} \\
\cline { 2 - 5 } & $\mathbf{3}$ & $\mathbf{6}$ & $\mathbf{9}$ & $\mathbf{1 2}$ \\
\hline Control & $5.37 \pm 0.15^{\mathrm{a}}$ & $6.37 \pm 0.21^{\mathrm{a}}$ & $8.95 \pm 0.13^{\mathrm{a}}$ & $10.06 \pm 0.16^{\mathrm{a}}$ \\
$0.5 \%$ olive leaf & $5.33 \pm 0.36^{\mathrm{a}}$ & $6.33 \pm 0.25^{\mathrm{a}}$ & $8.99 \pm 0.31^{\mathrm{a}}$ & $10.02 \pm 0.27^{\mathrm{a}}$ \\
$1.5 \%$ olive leaf & $4.2 \pm 0.1^{\mathrm{b}}$ & $5.37 \pm 0.15^{\mathrm{b}}$ & $7.5 \pm 0.17^{\mathrm{b}}$ & $8.84 \pm 0.03^{\mathrm{b}}$ \\
$2.5 \%$ olive leaf & $4.13 \pm 0.12^{\mathrm{b}}$ & $3.67 \pm 0.15^{\mathrm{c}}$ & $5.47 \pm 0.25^{\mathrm{c}}$ & $6.23 \pm 0.05^{\mathrm{c}}$ \\
\hline
\end{tabular}

* Means within each column with the same superscript letter $\left({ }^{a, b, c}\right)$ are not significantly different.

\subsection{Antimicrobial Activity of the Olive Leaf Extract on Total Coliform Bacteria of the Sheep Meat Slides}

The initial determination of total count bacteria of the fresh sheep meat slides was $1.5 \log \mathrm{CFU} / \mathrm{g}$, as shown in Table 4 . Thereafter, the results showed that the total coliform bacteria spectacularly increased during 12 days of storage at $5{ }^{\circ} \mathrm{C}$ in both the control sample and the sheep meat slides treated with olive leaf extracts. The statistical analysis showed that there was no significant difference $(p>0.05)$ between the control sample and the $0.5 \%$ olive leaf extract during 12 days of cold storage, 
whereas both the $1.5 \%$ and $2.5 \%$ olive leaf extract were statistically significant compared to the control sample and the $0.5 \%$ olive leaf extract during the same period of time. Furthermore, there was no significant difference $(p>0.05)$ between the $1.5 \%$ and $2.5 \%$ olive leaf extract during 3 and 6 days of the cold storage condition. However, the results found that the total coliform bacteria was statistically significant $(p<0.05)$ between the $1.5 \%$ and $2.5 \%$ olive leaf extracts at 9 and 12 days of the cold storage condition. The results showed that the sample treated with $2.5 \%$ olive leaf extract had low microbial counts (5.2 $\pm 0.35 \log \mathrm{CFU} / \mathrm{g}$ ) compared to the control, $0.5 \%$, and $1.5 \%$ olive leaf extract treated samples during the entire storage period of 12 days. Similar results were observed and reported by Rahman et al. [32].

Table 4. Effect of the olive leaf extract on total coliform bacteria $(\log \mathrm{CFU} / \mathrm{g})$ of the sheep meat slides stored at $5{ }^{\circ} \mathrm{C}$ for 12 days.

\begin{tabular}{ccccc}
\hline \multirow{2}{*}{ Treatment } & \multicolumn{4}{c}{ Number of Days $^{\text {* }}$} \\
\cline { 2 - 5 } & $\mathbf{3}$ & $\mathbf{6}$ & $\mathbf{9}$ & $\mathbf{1 2}$ \\
\hline Control & $3.13 \pm 0.32^{\mathrm{a}}$ & $5.09 \pm 0.21^{\mathrm{a}}$ & $7.89 \pm 0.4^{\mathrm{a}}$ & $9.11 \pm 0.23^{\mathrm{a}}$ \\
$0.5 \%$ olive leaf & $3.12 \pm 0.36^{\mathrm{a}}$ & $5.11 \pm 0.41^{\mathrm{a}}$ & $7.87 \pm 0.31^{\mathrm{a}}$ & $9.1 \pm 0.37^{\mathrm{a}}$ \\
$1.5 \%$ olive leaf & $2.32 \pm 0.21^{\mathrm{b}}$ & $3.09 \pm 0.13^{\mathrm{b}}$ & $5.1 \pm 0.31^{\mathrm{b}}$ & $6.87 \pm 0.27^{\mathrm{b}}$ \\
$2.5 \%$ olive leaf & $2.3 \pm 0.31^{\mathrm{b}}$ & $3.07 \pm 0.15^{\mathrm{b}}$ & $4.05 \pm 0.29^{\mathrm{c}}$ & $5.2 \pm 0.35^{\mathrm{c}}$ \\
\hline
\end{tabular}

* Means within each column with the same superscript letter $\left({ }^{a, b, c}\right)$ are not significantly different.

\section{Conclusions}

Methanol extraction produced the highest amount of phenolic compounds and antioxidant activity followed by ethanol extraction, diethyl ether extraction, and hexanol extraction. The phenolic extracts from the olive leaves possessed and exhibited reliable antioxidant and antimicrobial effects, which could be used as a source of potential antioxidant and antimicrobial agents. This study exhibited useful and beneficial information; therefore this obtained knowledge will be very helpful for the further exploitation and application of this resource.

Conflicts of Interest: The author declares no conflict of interest.

\section{References}

1. Taha, F. The development of olive cultivation. In General Company for Forestry and Horticulture; Ministry of Agriculture: Karradah AL-Sharkiya Baghdad, Iraq, 2007.

2. De Leonardis, A.; Acetini, A.; Alfano, G.; Macciola, V.; Ranalli, G. Isolation of a hydroxytyrosol rich extract from olive leaves (Olea europaea L.) and evaluation of its antioxidant properties and bioactivity. Eur. Food Res. Technol. 2008, 226, 653-659. [CrossRef]

3. Medina, I.; Gllardo, J.M.; Gonzalez, M.J.; Lois, S.; Hedges, N. Effect of Molecular Structure of Phenolic Families as Hydroxycinnamic Acid and Catechins on their Antioxidant Effectiveness in Minced Fish Muscle. J. Agric. Food Chem. 2007, 55, 3889-3895. [CrossRef] [PubMed]

4. Sallam, K.I.; Ishioroshi, M.; Samejima, K. Antioxidant and antimicrobial effects of garlic in chicken sausage. Lebenson Wiss Technol. 2004, 37, 849-855. [CrossRef] [PubMed]

5. Taamalli, A.; Arraez-Roman, D.; Zarrouk, M.; Valverde, J.; Segura-Carretero, A.; Wang, L.; Geng, C.; Jiang, L.; Gong, D.; Liu, D.; et al. The anti-atherosclerotic effect of olive leaf extract is related to suppressed inflammatory response in rabbits with experimental atherosclerosis. Eur. J. Nutr. 2008, 47, 235-243.

6. Gharavi, N.; Haggarty, S.; El-Kadi, A. Chemoprotective and carcinogenic effects of tert-butylhydroquinone and its metabolites. Curr. Drug. Metab. 2007, 8, 1-7. [CrossRef] [PubMed]

7. Loliger, J.; Lambelet, P.; Aeschbach, R.; Prior, E.M. Natural antioxidants: from radical mechanisms to food stabilization. In Food Lipids and Health; McDonald, R.E., Min, D.B., Eds.; Marcel Dekker Inc.: New York, NY, USA, 1996; pp. 68-77. 
8. Pokorny, J.; Yanishlieva, N.; Gordon, M. Antioxidants in Food Practical Applications; CRC Press: New York, NY, USA, 2000.

9. Gkanatsiou, K.; Kiritsakis, A.; Kiritsakis, K. The effect of saffron extracts (Crocus Sativus L.). In Preventing the Oxidation of Oils, Vol. 2; Hellenic Association of Food Technologists and Alexander Technological Educational Institute of Thessaloniki: Thessaloniki, Greece, 2007; pp. 595-604.

10. Pereira, A.P.; Ferreira, I.C.; Marcelino, F.; Valentão, P.; Andrade, P.B.; Seabra, R.; Pereira, J.A. Phenolic compounds and antimicrobial activity of olive (Olea europaea L. Cv. Cobrançosa) leaves. Molecules 2007, 12, 1153-1162. [CrossRef] [PubMed]

11. Sudjana, A.N.; D'Orazio, C.; Ryan, V.; Rasool, N.; Ng, J.; Islam, N. Antimicrobial activity of commercial Olea europaea (olive) leaf extract. Int. J. Antimicrob. Agents 2009, 33, 461-463. [CrossRef] [PubMed]

12. De Bock, M.; Thorstensen, E.B.; Derraik, J.G.; Henderson, H.V.; Hofman, P.L.; Cutfield, W.S. Human absorption and metabolism of oleuropein and hydroxytyrosol ingested as olive (Olea europaea L.) leaf extract. Mol. Nutr. Food Res. 2013, 57, 2079-2085. [CrossRef] [PubMed]

13. Haddadin, M.S.Y. Effect of Olive Leaf Extracts on the Growth and Metabolism of Two Probiotic Bacteria of Intestinal Origin. Pak. J. Nutr. 2010, 9, 787-793. [CrossRef]

14. Lako, J.; Trenerry, V.C.; Wahlqvist, M.; Wattanapenpaiboon, N.; Sotheeswaran, S.; Premier, R. Carotenoids, and the Antioxidant Properties of a Wide Selection of Fijian Fruit, Vegetables and Other Readily Available Foods. Food Chem. 2007, 101, 1727-1741. [CrossRef]

15. Elmastas, M.; Isildak, O.; Turkekul, I.; Temur, N. Determination of antioxidant activity and antioxidant compounds in wild edible mushrooms. J. Food Compos. Anal. 2007, 20, 337-345. [CrossRef]

16. Oyaizu, M. Studies on products of browning reactions: Antioxidative activities of products of browning reaction prepared from glucosamine. Jpn. J. Nutr. 1986, 44, 307-315. [CrossRef]

17. Braca, A.; Sortino, C.; Politi, M.; Morelli, I.; Mendez, J. Antioxidant activity of flavonoids from Licania licaniaeflora. J. Ethnopharmacol. 2002, 79, 379-381. [CrossRef]

18. Yateem, H.; Afaneh, I.; Al-Rimawi, F. Optimum conditions for oleuropein extraction from olive leaves. Int. J. Appl. 2014, 4, 153-157.

19. Aytul, K.K. Antimicrobial and Antioxidant Activities of Olive Leaf Extract and Its Food Applications. MSc. Thesis, Engineering and Sciences of Izmir Institute of Technology, Izmir, Turkey, 12 July 2010.

20. Bekhit, A.E.D.; Geesink, G.H.; Ilian, M.A.; Morton, J.D.; Bickerstaffe, R. The Effects of Natural Antioxidants on Oxidative Process and Metmyoglobin Reducing Activity in Sheep meat Patties. Food Chem. 2003, 81, 175-187. [CrossRef]

21. Andrews, J.M. Determination of Minimum Inhibition Concentrations. J. Antimic. Chemother. 2001, 48, 5-16. [CrossRef]

22. Zhou, K.; Yu, L. Effects of extraction solvent on wheat bran antioxidant activity estimation. LWT 2004, 37, 717-721. [CrossRef]

23. Ilango, K.; Chitra, V.; Kanimozhi, P.; Balaji, G. Antidiabetic, Antioxidant and Antibacterial Activities of Leaf extracts of Adhatoda zeylanica. Medic (Acanthaceae). J. Pharm. Sci. Res. 2009, 1, 67-73.

24. Aliyu, A.B.; Ibrahim, M.A.; Musa, A.M.; Ibrahim, H.; Abdulkadir, I.E.; Oyewale, A.O. Evaluation of antioxidant activity of leave extract of Bauhinia rufescens Lam. (Caesalpiniaceae). J. Med. Plants Res. 2009, 3, 563-567.

25. Hamad, I. Antioxidant activity and potential Hepato- protective effect of Saudi olive leaf extract. In Proceedings of the 2nd International Conference on Advances in Environment, Agriculture \& Medical Sciences, Antalya, Turkey, 11-12 June 2015.

26. Rezaeizadeh, A.; Zuki, A.B.Z.; Abdollahi, M.; Goh, Y.M.; Noordin, M.M.; Hamid, M.; Azmi, T.I. Determination of antioxidant activity in methanolic and chloroformic extracts of Momordica charantia. Afr. J. Biotechnol. 2011, 10, 4932-4940.

27. Altemimi, A.; Choudhary, R.; Watson, D.G.; Lightfoot, D.A. Effects of ultrasonic treatments on the polyphenol and antioxidant content of spinach extracts. Ultrason. Sonochem. 2015, 24, 247-255. [CrossRef] [PubMed]

28. Fernandez-Gutierrez, A. The occurrence and bioactivity of polyphenols in Tunisian olive products and byproducts: A review. J. Food Sci. 2012, 77, R83-R92.

29. Obied, H.K.; Bedgood, D.R.; Prenzler, P.D.; Robards, K. Effect of processing conditions, prestorage treatment, and storage conditions on the phenol content and antioxidant activity of olive mill waste. J. Agric. Food Chem. 2008, 56, 3925-3932. [CrossRef] [PubMed] 
30. Verma, S.P.; Sahoo, J. Synergistic effect of L-ascorbic acid and $\alpha$-tocopherol acetate on the quality of ground chevon during refrigerated storage. J. Food Sci. Technol. 2001, 38, 220-226.

31. Ahmed, A.M.; Rabii, N.S.; Garbaj, A.M.; Abolghait, S.K. Antibacterial effect of olive (Olea europaea L.) leaves extract in raw peeled undeveined shrimp (Penaeus semisulcatus). Int. J. Vet. Sci. Med. 2014, 2, 53-56. [CrossRef]

32. Rahman, M.M.; Akhter, S.; Jamal, M.A.H.M.; Pandeya, D.R.; Haque, M.A.; Alam, M.F.; Rahman, A. Control of coliform bacteria detected from diarrhea associated patients by extracts of Moringa oleifera. Nepal. Med. Coll. J. 2010, 12, 12-19. [PubMed]

(C) 2017 by the author. Licensee MDPI, Basel, Switzerland. This article is an open access article distributed under the terms and conditions of the Creative Commons Attribution (CC BY) license (http://creativecommons.org/licenses/by/4.0/). 